\title{
The Identification of SNPs in BCDO2 Gene for Skin Color in Chinese Indigenous Chicken
}

\section{Euthor(s)

Kong FL'
Chen SY'
Ran JS'
Yang CW"'
Jiang XS"
Lan D'
Hu YD'
Liu YP'

Farm Animal Genetic Resources Exploration and Innovation Key Laboratory of Sichuan Province-Sichuan Agricultural University, Sichuan 611130, China

" Sichuan Animal science academy, Chengdu 610066, China

\section{ABSTRACT}

A complete linkage disequilibrium between the SNP (SNP B) in $B C D O 2$ gene and the yellow skin phenotype in European domestic chicken has been reported. Here, we genotyped the reported SNPs (SNP $A$, SNP B, and SNP C) of the BCDO2 gene in 183 Chinese Indigenous chickens from 11 breeds/populations, including 57 yellow, 17 white, and 109 black skin chickens. The frequency of all three SNPs were significantly different between yellow and white skin chickens $(p<0.01)$. In black skin chickens, a high frequency of the heterozygous genotype (AG) in SNP A (0.51) and SNP B (0.48) was observed. A total of three haplotypes (AAA, AGA, and GAA) from these three SNPs were obtained. Frequencies of the proposed yellow skin-associated haplotype AGA in yellow skin, white skin, and black skin chickens were $0.81,0.35$, and 0.56 , respectively. The results showed that the yellow skin phenotype of the evaluated birds has not been under selection, and that the $B C D O 2$ gene in black skin chickens, evolutionally may undergo a transition phase from yellow to white skin chicken. We concluded that, the SNPs of $B C D O 2$ gene not only can be used to determine whether the chicken was subjected to selection, but may also be used as a marker when selecting for the preferred skin color in chicken breeding programs.

\section{INTRODUCTION}

The skin color of chicken is an important phenotype, and may influence consumers' decision. Chickens with the yellow skin phenotype are widely preferred in USA, Mexico, and China. It is one of the first traits in animals described to exhibit Mendelian inheritance, and it is caused by one or more cis-acting and tissue-specific regulatory mutations that inhibit expression of $\beta$-carotene dioxygenase 2 (BCDO2) in the skin (Eriksson et al., 2008).

The $\beta$-carotene dioxygenase 2 gene (BCDO2), located in chromosome 24 , has been proposed as a candidate gene for the yellow skin phenotype in chickens (Schmid et al., 2000), and was validated by Yang et al., (2012). BCDO2 gene encodes $\beta$-carotene dioxygenase 2 , an enzyme that cleaves colorful $\beta$-carotenoids into colorless apocarotenoids by an asymmetric cleavage reaction, leading to white skin (Kieferet al., 2001). Based on the linkage mapping within families and identical-bydescent analysis across breeds with yellow skin phenotype in domestic chickens, Eriksson et al. (2008) reported an association of the three single nucleotide polymorphisms (SNPs: $\mathrm{A}, \mathrm{B}$, and $\mathrm{C}$ ) around $\mathrm{BCDO2}$ gene with the yellow skin phenotype, and also that the $B C D O 2$ gene presented fairly strong expression in the liver and the skin. In addition to skin color in chickens, the $B C D O 2$ gene was also reported to play important roles in carotenoid metabolism in different farm animals, such as cattle and sheep. Berry et al. (2009) and Tian et al. (2010) showed 
Kong FL, Chen SY, Ran JS, Yang CW, Jiang XS, Lan D, Hu YD, Liu YP

\section{The Identification of SNPs in BCDO2 Gene for Skin Color in Chinese Indigenous Chicken}

that the loss of function of the $B C D O 2$ gene increased the levels of $\beta$-carotene, resulting in the yellow color of milk and serum in cows. A nonsense mutation (c.196C $>T$ ) of the $B C D O 2$ gene was also found to be strongly associated with yellow fat in sheep (Våge DI \& Boman IA, 2010).

In southwest China, the black skin chicken is one of the most important genetic lines. The black skin chicken (also known as the Silkie chicken) has been long used in natural medicine. Its genetic control and biology of dermal hyperpigmentation have been studied (Dorshorst et al., 2010). Black skin was shown to be caused by a mutation of the MC1R gene (Kerje et al., 2003). The BCDO2 allele was thought to be acquired through hybridization with the Gray Jungle fowl of South Asia, which means that the domestic chicken has a hybrid origin. It was reported that the black skin trait was first found in India and then transferred to China and Japan (Roberts, 2009), which indicates that Chinese black skin Silkieis crossbred of many different genetic lines of chickens (Fu, 2002; Liu et al., 2006; Zhou et al., 2010). However, the SNPs of BCDO2 gene in black skin chicken have not been identified yet. The aim of this study was to detect the three SNPs around the $\mathrm{BCDO} 2$ gene in Chinese indigenous chickens, especially in the black skin chicken.

\section{MATERIALS AND METHODS}

\section{Sample collection}

Blood samples were collected from 183 individuals, including 57 chickens with yellow skin from four breeds, 17 chickens with white skin from one breed, and 109 chickens with black skin from six breeds/ populations. All birds were older than 12 weeks of age at the time of sampling, and their skin color was optically recognized (Table 1). Blood samples were collected and stored at $-80{ }^{\circ} \mathrm{C}$ freezer.

\section{Genotyping analysis}

Genomic DNA was extracted by using standard phenol/chloroform method. Three primer pairs were designed to independently amplify three fragments encompassing the three proposed SNPS (Table 2), including SNP A $(g 6,264,085 G \rightarrow A)$, SNP B $(g 6,273,428 A \rightarrow G)$, and SNP C $(g 6,287,900 G \rightarrow A)$ in the BCDO2 gene (GenBank no. NC_006111.3). The primer pairs were all synthesized by Shanghai Invitrogen Biology Technique Corporation.

PCR amplification was performed in a $50 \mu \mathrm{L}$ reaction mixture containing 100ng genomic DNA, 25 $\mu \mathrm{L} 2 \times$ MasterMix (Beijing Tianwei Biology Technique Corporation, Beijing, China), and $2 \mu \mathrm{L}$ of each primer $(10 \mu \mathrm{M})$. PCR conditions included an initial denaturation cycle at $95^{\circ} \mathrm{C}$ for $5 \mathrm{~min}$, followed by 35 cycles of $95^{\circ} \mathrm{C}$ for $1 \mathrm{~min}$, appropriate annealing temperature $\left(51.4^{\circ} \mathrm{C}\right.$ for primer pair $\mathrm{A}, 53.3^{\circ} \mathrm{C}$ for primer pair $\mathrm{B}$ and $54.7^{\circ} \mathrm{C}$ for primer pair $\mathrm{C}$ ) for $1 \mathrm{~min}$, and extension at $72^{\circ} \mathrm{C}$ for $2 \mathrm{~min}$. PCR products were detected in 1\% agarose gel and were visualized on Gel TMEQ170-8060 and then photographed. PCR products were purified and sequenced by Shanghai Invitrogen Biology Technique Corporation (Shanghai, China).

\section{Statistical analysis}

Sequences were aligned by using DNASTAR package (DNASTAR, Madison, WI) with manual inspection. After the genotype and allele frequencies were directly counted, Hardy-Weinberg equilibrium (HWE) was

Table 1 - Skin color and samples evaluated in this study and allele frequencies at SNPs around the BCDO2gene with yellow skin haplotype.

\begin{tabular}{|c|c|c|c|c|c|c|c|}
\hline Skin color & $\mathrm{N}$ & Breeds & Sample IDs & Location & $\operatorname{SNP} A(A)$ & $\operatorname{SNPB}(G)$ & SNP C (A) \\
\hline \multirow[t]{4}{*}{ Yellow skin } & 12 & Fengkaixinghua & FX & Guangdong, China & 1 & 0.72 & 1 \\
\hline & 10 & Huxu ${ }^{1}$ & $H X$ & Guangdong, China & 0.94 & 1 & 1 \\
\hline & 20 & Qinyuan ${ }^{1,2}$ & QY & Guangdong, China & 1 & 1 & 1 \\
\hline & 15 & Xiayan $^{1}$ & $X Y$ & Jiangxi, China & 0.89 & 0.73 & 1 \\
\hline \multirow[t]{6}{*}{ Black skin } & 20 & Caoke $^{1,2}$ & CK & Sichuan, China & 0.43 & 0.5 & 0.75 \\
\hline & 14 & Junlian Black-boned & $J$ & Sichuan, China & 0.14 & 0.11 & 1 \\
\hline & 20 & Jiuyuan Black-boned² & JY & Sichuan, China & 0.43 & 0.42 & 1 \\
\hline & 22 & Shandi Black-boned & SD & Sichuan, China & 0.36 & 0.39 & 0.98 \\
\hline & 22 & Taihe Silky ${ }^{1,2}$ & SK & Jiangxi, China & 0.30 & 0.29 & 1.00 \\
\hline & 11 & Tibetan $^{1}$ & $\mathrm{~TB}$ & Sichuan, China & 0.41 & 0.45 & 0.95 \\
\hline White skin & 17 & Chahua $^{1}$ & $\mathrm{CH}$ & Yunnan, China & 0.77 & 0.35 & 1.00 \\
\hline Total & 183 & - & - & - & & & \\
\hline
\end{tabular}

${ }^{1}$ These samples had been analyzed in our former study of the phylogeny and genetic diversity of domestic chicken (Liu et al., 2006).

${ }^{2}$ These breeds were collected from the local conservation farms. 
Table 2 - Primers pairs of PCR amplification for direct sequencing

\begin{tabular}{|c|c|c|c|}
\hline Primer pairs & Sequences $\left(5^{\prime}-3^{\prime}\right)$ & Annealing temperature $\left({ }^{\circ} \mathrm{C}\right)$ & Fragment length (bp) \\
\hline $\begin{array}{l}\text { SNP A } \\
(\mathrm{g} 6,264,085 \mathrm{G} \rightarrow \mathrm{A})\end{array}$ & $\begin{array}{l}\text { GAGAAGATGCCCTGGATTA } \\
\text { TTGAGTGGTGGTGGTGATA }\end{array}$ & 51 & 802 \\
\hline $\begin{array}{l}\text { SNP B } \\
(\mathrm{g} 6,273,428 \mathrm{~A} \rightarrow \mathrm{G})\end{array}$ & $\begin{array}{l}\text { TTGGGCTAAGAAGTGGGAAG } \\
\text { CATGAGCTCGTCATGGTCAA }\end{array}$ & 53 & 983 \\
\hline $\begin{array}{l}\text { SNPC } \\
(g 6,287,900 G \rightarrow A)\end{array}$ & $\begin{array}{l}\text { CTGCTCGTCATCGTTACCT } \\
\text { TGCGGACATCCATTTACAC }\end{array}$ & 55 & 742 \\
\hline
\end{tabular}

analyzed by the $\chi 2$ test. Fisher's exact test (two-tailed) was performed to quantify the statistical difference. The $p$ value with Bonferroni correction of $<0.05$ was regarded as statistically significant. Haplotypes were constructed by using Phase 2.0.

\section{RESULTS AND DISCUSSION}

The $B C D O 2$ gene is an excellent candidate for explaining the variation in carotenoid-based pigmentation observed in many other vertebrate species. In this study, we identified the distribution of three SNPs $(A, B, C)$ of the $B C D O 2$ gene in Chinese indigenous chickens presenting three skin colors (shown in Table 3) based on the study of Eriksson et al. (2008). All three SNPs were substitutions of AVG. The frequency distribution of three SNPs significantly differed among the three skin colors. The allele frequencies of the three proposed yellow skin-associated nucleotides $A$ (SNP A), G (SNP B), and A (SNP C) were 0.96, 0.88, and 1.00 in yellow skin chickens; $0.77,0.35$, and 1.00 in white skin chickens; and $0.35,0.37$, and 0.95 in black skin chickens. For SNP A, the AA genotype (0.91) was predominant in yellow skin chickens, and was less abundant in white skin chickens (0.70) and black skin chickens (0.09). A similar genetic pattern was observed for SNP B, with the highest and lowest frequencies of the GG genotype in yellow skin chickens (0.81) and black skin chickens (0.12), respectively. For SNP C, the AA genotype presented complete penetrance in both yellow skin and white skin chickens, but in black skin chickens, it accounted for the highest frequencies

Table 3 - Genotype and allele frequencies of three SNPs of the BCDO2 gene in Chinese indigenous chickens.

\begin{tabular}{|c|c|c|c|c|c|c|}
\hline \multirow[t]{2}{*}{ Genotypes / alleles } & \multirow[t]{2}{*}{ Yellow skin $(Y, n=57)$} & \multirow[t]{2}{*}{ White $\operatorname{skin}(W ; n=17)$} & \multirow[t]{2}{*}{ Black skin $(B, n=109)$} & \multicolumn{3}{|c|}{ Pairwise comparison } \\
\hline & & & & Y vs. W & Y vs. B & W vs. B \\
\hline \multicolumn{7}{|l|}{ SNP A } \\
\hline $\mathrm{GG}$ & $0(0.0)$ & $3(0.18)$ & $43(0.40)$ & $<0.01$ & $<0.01$ & 0.08 \\
\hline$A G$ & $5(0.09)$ & $2(0.12)$ & $56(0.51)$ & 0.71 & $<0.01$ & $<0.01$ \\
\hline AA & $52(0.91)$ & $12(0.70)$ & $10(0.09)$ & 0.03 & $<0.01$ & $<0.01$ \\
\hline A & $109(0.96)$ & $26(0.77)$ & $76(0.35)$ & \multirow{2}{*}{$<0.01$} & \multirow{2}{*}{$<0.01$} & \multirow{2}{*}{$<0.01$} \\
\hline G & $5(0.04)$ & $8(0.23)$ & $142(0.65)$ & & & \\
\hline$H W E^{a}$ & 0.73 & 0.01 & 0.17 & - & - & - \\
\hline \multicolumn{7}{|l|}{ SNP B } \\
\hline AA & $3(0.05)$ & $11(0.65)$ & $43(0.40)$ & $<0.01$ & $<0.01$ & 0.05 \\
\hline$A G$ & $8(0.14)$ & $0(0.0)$ & $52(0.48)$ & 0.10 & $<0.01$ & $<0.01$ \\
\hline $\mathrm{GG}$ & $46(0.81)$ & $6(0.35)$ & $14(0.12)$ & $<0.01$ & $<0.01$ & 0.02 \\
\hline A & $14(0.12)$ & $22(0.65)$ & $138(0.63)$ & \multirow{2}{*}{$<0.01$} & \multirow{2}{*}{$<0.01$} & \multirow{2}{*}{0.87} \\
\hline G & $100(0.88)$ & $12(0.35)$ & $80(0.37)$ & & & \\
\hline HWE & 0.07 & $<0.01$ & 0.78 & - & - & - \\
\hline \multicolumn{7}{|l|}{ SNP C } \\
\hline GG & $0(0.0)$ & $0(0.0)$ & $0(0.0)$ & - & - & - \\
\hline$A G$ & $0(0.0)$ & $0(0.0)$ & $12(0.11)$ & - & 0.01 & 0.15 \\
\hline AA & $57(1.00)$ & $17(1.00)$ & $97(0.89)$ & - & 0.01 & 0.15 \\
\hline$A$ & $57(1.00)$ & $34(1.00)$ & $206(0.95)$ & \multirow{2}{*}{-} & \multirow{2}{*}{0.07} & \multirow{2}{*}{0.16} \\
\hline G & $0(0.0)$ & $0(0.0)$ & $12(0.05)$ & & & \\
\hline HWE & - & - & 0.54 & - & - & - \\
\hline \multicolumn{7}{|c|}{ Haplotypes (SNP A- SNP B- SNP C) } \\
\hline AAA & $9(0.19)$ & $9(0.53)$ & $7(0.06)$ & 1.00 & 0.02 & $<0.01$ \\
\hline$A G A$ & $38(0.81)$ & $6(0.35)$ & $60(0.56)$ & $<0.01$ & $<0.01$ & 0.12 \\
\hline GAA & $0(0.0)$ & $2(0.12)$ & $41(0.38)$ & 0.02 & $<0.01$ & 0.02 \\
\hline
\end{tabular}

${ }^{a}$ Chi-square test values $<0.05$ are considered as deviated from HWE. 
Kong FL, Chen SY, Ran JS, Yang CW, Jiang XS, Lan D, Hu YD, Liu YP

\section{The Identification of SNPs in BCDO2 Gene for Skin Color in Chinese Indigenous Chicken}

(0.89). The frequencies of SNP A, B and C detected in white skin chickens were not consistent with a previous study (Eriksson et al., 2008), but significant SNP A and SNP B differences between yellow skin and white skin chickens were detected $(p<0.01)$. In addition, SNP A and SNP B also presented deviation from the HWE in white skin chickens (Table 3). Possible explanations for this inconsistency may be the involvement of additional genes in the biogenesis of the yellow skin in domestic chickens, or this skin color in chickens may be the result of artificial selection. However, because only one white skin breed with 17 samples was analyzed in the present study, no definitive conclusions can be made. Nevertheless, Yang et al. (2012) observed all 30 Chahua chickens from China presented homozygous AA in the SNP B locus, which was consistent with previous results (Eriksson et al., 2008), providing further support to our results.

A total of three haplotypes (AAA, AGA, and GAA, shown in Table 3 and Figure 1) was detected in all chickens. Only two haplotypes (AAA and AGA) were observed in yellow skin chickens, while all three haplotypes were detected in white and black skin chickens. The frequencies of the proposed yellow skin-associated haplotype (AGA) accounted for 0.81, 0.35 and 0.56 in yellow skin, white skin, and black skin individuals, respectively. In addition, the frequency of the haplotype AGA of the yellow skin chicken was significantly different compared with white and black skin chickens, but no statistical difference was detected between white skin and black skin chickens.

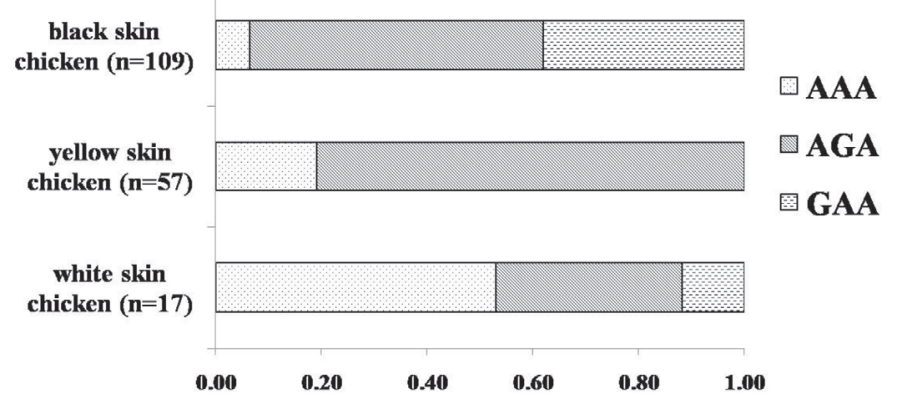

Figure $\mathbf{1}$ - Schematic illustration of the haplotype composition of the different skin color types. The axis represents the frequency of each haplotype.

Based on the sequence similarity, Eriksson et al. (2008) proposed the hybrid origin of the modern domestic chickens based on the fact that the yellow skin-associated haplotype was originated from the grey jungle fowl (Gallus sonneratii) rather than from the red jungle fowl (Gallus gallus), because the grey jungle fowl (Gallus sonneratii) has yellow skin, while the red jungle fowl has white skin (which is called Chahua chicken in China). Chicken skin color can be stably recognized until 12-14weeks of age under the same feeding conditions (Crawford, 1990). In this study, we found high frequencies of the heterozygous genotype (AG) in SNP A (0.51) and SNP B (0.48), but not in SNP C (0.11). Therefore, we hypothesize that the black skin chicken would be an intermediate type, that is, that the black skin is a transition between white and yellow, or may be a hybridization of yellow and white skin chickens. This would provide useful clues to investigate the biogenesis of black skin in these breeds/populations.

In summary, skin color, as a classic phenotypic trait, plays an important role in breed recognition and breeding selection in farm animals. We reconfirmed that the $B C D O 2$ gene is present in Chinese indigenous yellow skin chickens, and plays an important role in their skin color. However, its incomplete link with yellow skin also indicates a more complex role of the $B C D O 2$ gene underlying the biogenesis of skin color in domestic chickens.

\section{CONCLUSION}

Based on the results of this study, we speculate that there are significant associations between skin colors and genetic variants of the $B C D O 2$ gene in Chinese domestic chickens, and that the $B C D O 2$ gene may be used as a marker gene to identify skin color for chicken breeding. However, as it is a complex trait, skin color is determined by a complex pathway system and multiple interactive patterns, and therefore, further studies are warranted to confirm this conclusion.

\section{ACKNOWLEDGEMENTS}

This study was supported by the Programs from Sichuan Province (2011NZ0099-7; 15FZ0036; 2015NZ0091).

\section{REFERENCES}

Berry SD, Davis SR, Beattie EM, Thomas NL, Burrett AK, Ward HE, et al. Mutation in bovine $\beta$-carotene oxygenase 2 affects milk color. Genetics 2009; 182(4):923-926.

Crawford RD. Poultry breeding and genetics: developments in animal and veterinary sciences [book 22]. $7^{\text {th }}$ ed. Amsterdam: Elsevier; 1990.

Dorshorst B, Okimoto R, Ashwell C. Genomic regions associated with dermal hyperpigmentation, polydactyly and other morphological traits in the Silkie chicken. Journal of Heredity 2010;101(1):339-350.

Eriksson J, Larson G, Gunnarsson U, Bed'hom B, Tixier-Boichard M, Strömstedt $L$, et al. Identification of the yellow skin gene reveals a hybrid origin of the domestic chicken. PLoS Genet 2008;25(1):4

Fu Y. Studies on genetic relationship between silky chicken and other breeds. Chinese Journal of Animal Science 2002;38(1):5-6. 
Kerje S, Lind J, Schütz K, Jensen P, Andersson L. Melanocortin 1-receptor (MC1R) mutations are associated with plumage colour in chicken. Animal Genetics 2003;34(1):241-248.

Kiefer C, Hessel S, Lampert JM, Vogt K, Lederer MO, Breithaupt DE, et al. Identification and characterization of a mammalian enzyme catalyzing the asymmetric oxidative cleavage of provitamin A. Journal of Biological Chemistry 2001;276(1):14110-14116.

Liu YP, Wu GS, Yao YG, Miao YW, Luikart G, Baig M, et al. Multiple maternal origins of chickens:out of the Asian jungles. Molecular Phylogenetics and Evolution 2006;38(1):12-19.

Roberts V. British poultry standards. $6^{\text {th }}$ ed. Oxford: John Wiley \& Sons; 2008.

Schmid M, Nanda I, Guttenbach M, Steinlein C, Hoehn M, Schartl M, et al. First report on chicken genes and chromosomes 2000. Cytogenetic and Genome Research 2000;90(1):169-172.
Tian R, Pitchford W, Morris C, Cullen N, Bottema C. Genetic variation in the $\beta, \beta$-carotene- $9^{\prime}, 10^{\prime}$-dioxygenase gene and association with fat colour in bovine adipose tissue and milk. Animal Genetics 2010:41(1):253259.

Våge DI, Boman IA. A nonsense mutation in the beta-carotene oxygenase 2 (BCO2) gene is tightly associated with accumulation of carotenoids in adipose tissue in sheep (Ovis aries). BMC Genetics 2010;11(1):1.

Yang X, Li J, Deng X. Polymorphism of BCDO2 gene for the yellow shank color in chicken. China Poultry 2012;8(1):5.

Zhou B, Chen SY, Zhu Q, Yao YG,Liu YP. Matrilineal components and genetic relationship of Silkies from China and Japan. The Journal of Poultry Science 2010;47(1):22-27. 
